\title{
Antibacterial Activity and Composition of the Fermentation Broth of
}

\section{Streptomyces Parvus 33}

\author{
Wenjuan Zhang, ${ }^{1}$ Saijian $\mathrm{Ma},{ }^{2}$ Chao $\mathrm{An},{ }^{2}$ and Wenjiao Xue ${ }^{2, *}$ \\ ${ }^{1}$ Weinan Vocation and Technical College, Weinan, Shaanxi Province, 714026, P. R. China \\ ${ }^{2}$ Microbiology Institute of Shaanxi, 76 Xiying Rd, Xi'an, Shaanxi Province, 710043, P. R. China \\ "Corresponding author: Wenjiao Xue, Microbiology Institute of Shaanxi, 76 Xiying Rd, Xi'an, Shaanxi Province, 710043, P. R. China. Tel: +86-02985350847, E-mail: \\ 346970057@163.com
}

Received 2017 June 05; Accepted 2017 June 24.

\begin{abstract}
Background: Microorganisms represent a potentially valuable source of biologically significant compounds that should be explored for their potential agrochemical use.

Objectives: The compounds ZM-1 and ZM-2 were isolated from the extract of the fermentation broth of Streptomyces parvus 33 by bioassay-guided fractionation.

Methods: The compound ZM-1 was isolated in the form of a clear single crystal for the first time, and identified as holomycin via X-ray crystallography. The compound ZM-2 was characterized by IR, ${ }^{1} \mathrm{H}-\mathrm{NMR},{ }^{13} \mathrm{C}-\mathrm{NMR}, \mathrm{DEPT}\left(90^{\circ}\right.$ and $\left.135^{\circ}\right)$, and MS analyses.

Results: The compound ZM-1 showed a strong antibacterial activity against the tested bacteria, and its value of minimum inhibitory concentration (MIC) was greater than that of the positive control Ampicillin. The compound ZM-1 also exhibited significant antimicrobial activities against some plant pathogenic fungi. Nevertheless, ZM-2 showed no activities against the tested bacteria and plant pathogenic fungi.

Conclusions: The compound ZM-1 was isolated in the form of a clear single crystal for the first time, and identified as holomycin via X-ray crystallography. Streptomyces parvus 33 is a newly discovered producer of holomycin. ZM-1 showed a strong antibacterial activity against the tested bacteria. Therefore, the compound ZM-1 is a valuable lead compound for the development of agricultural fungicides while acts against bacteria, as well.
\end{abstract}

Keywords: Anti-Bacterial Agents, Crystal, Streptomyces

\section{Background}

Bacterial and fungal plant diseases pose a major threat to agricultural production worldwide $(1,2)$. Nowadays, it remains a global challenge to develop new therapeutic modalities for treating infectious diseases caused by bacterial and fungal pathogens. A wide range of important secondary metabolites, including antibiotics and growth promoting substances, are produced by several members of Actinomycetes $(3,4)$. More than $60 \%$ of the nearly 6000 antibiotics of microbial origin are produced by Streptomyces spp. including both antibacterial and antifungal agents beside a considerable number of other bioactive compounds (5-11). Microorganisms represent a potentially valuable source of biologically significant compounds that should be explored for their potential agrochemical use (12). Soil strains of Actinomycetes are still important sources of novel antibiotics.

In the past decades, although many species, which produce biologically active metabolites, have been obtained from soil samples, the chance of isolating a new Actinomycete strain from a common terrestrial habitant has reduced markedly. In the process of screening new agricul- tural antibiotics, researchers have to look for novel microorganisms in unusual environments. Chemically polluted soil is one sort of such unusual environments. Chemical pollutants could be mutagens, and some of the mutant strains might give rise to increased productivity of bioactive metabolites, or even produce new bioactive compounds $(13,14)$.

\section{Objectives}

In this study, we report the compounds ZM-1 and ZM-2 of the fermentation broth of Streptomyces parvus 33, which was isolated from the chemically polluted soil samples. The compound ZM-1 was isolated in the form of a clear crystal for the first time.

\section{Methods}

\subsection{General Materials and Selected Microorganism}

Solvents were of analytical grade (AR) unless otherwise mentioned. TLC was performed on 60 F254 silica gel plates (Merck, USA). Column chromatography was used on 
HPD100 macroporous resin (Baoen, China) with methanol elution ( $\mathrm{MeOH}$, qingdao marine chemical, China). A Waters 2692 HPLC apparatus (Waters, USA) equipped with a Sinochrom ODS-BP $(10 \times 300 \mathrm{~mm}, 10 \mu \mathrm{m}$, Shimadzu, Japan $)$ reverse phase column was employed using methanolwater as mobile phase at flow rate of $3.0 \mathrm{~mL} / \mathrm{min}$, monitored by UV detector at $240 \mathrm{~nm}$.

The selected microorganism: Pathogenic bacteria were Solanacearum (Ralstonia solanacearum), Pseudomonas syringae pv. Actinidiae provided by the college of plant protection, Northwest A and F University. Bacillus cereus (Waxy bacillus, 1.184), B. subtilis (Bair conditionerillus subtilis, 1.88), P. aeruginosa (1.2031), Staphylococcus aureus (1.89), and Escherichia coli (1.1574) were purchased from China general microbiological culture collection center. The pathogenic bacteria were inoculated in beef extract peptone agar culture medium at $37^{\circ} \mathrm{C}$ for 1 day. Pathogenic fungi were Fusarium graminerum, Curvularia lunata, Colletotrichum orbiculare, C. gloesporioides provided by the College of Plant Protection, Northwest A \& F University. The inoculation of the pathogenic fungi was carried out in potato dextrose agar (PDA) medium at $25^{\circ} \mathrm{C}$ for $3-7$ days.

\subsection{Isolation and Identification of Streptomyces parvus 33}

The strain 33 was isolated from a chemically polluted soil sample collected from the Shaanxi province of China. According to the results of morphological examination and culture characteristics, physiology and biochemical measurement and 16S rDNA sequence analysis, the strain 33 was highly homological (up to 99\%) with S. parvus NRRLB-1455T (Figure 1). Therefore, the strain 33 was identified and designated as $S$. parvus 33. The voucher specimen of the Streptomycete was deposited in the Microbiology Institute of Shaanxi, China.

Streptomyces parvus 33 was cultivated at $28^{\circ} \mathrm{C}$ in Gause's medium, which contained soluble starch (2\%), $\mathrm{K}_{2} \mathrm{HPO}_{4}$ (0.05\%), $\mathrm{KNO}_{3}$ (0.1\%), $\mathrm{NaCl}(0.05 \%), \mathrm{MgSO}_{4} \bullet 7 \mathrm{H}_{2} \mathrm{O}(0.05 \%)$, $\mathrm{FeSO}_{4} \bullet 7 \mathrm{H}_{2} \mathrm{O}(0.001 \%)$, and $\operatorname{agar}(1.5 \%), \mathrm{pH}=7.2-7.4$. Fermentation was performed in two stages: seed growth and production. The spores of strain 33 grown on Gause's medium were used to inoculate a $250 \mathrm{~mL}$ flask containing $60 \mathrm{~mL}$ of a sterile seed medium consisting of glucose (1.0\%), millet steep liquor (1.0\%), peptone (0.5\%), ( $\mathrm{NH} 4)_{2} \mathrm{SO}_{4}(0.1 \%), \mathrm{NaCl}$ (0.25\%), and $\mathrm{CaCO}_{3}$ (0.05\%), pH 7.2. The flask was shaken on a shaker at $180 \mathrm{rpm}$ for $18 \mathrm{~h}$ at $28^{\circ} \mathrm{C} .6 \mathrm{~mL}$ of the seed culture were transferred to $250 \mathrm{~mL}$ flasks containing $60 \mathrm{~mL}$ of a sterile production medium consisting of glucose (1.0\%), millet steep liquor (1.0\%), peptone (0.3\%), $\left(\mathrm{NH}_{4}\right) 2 \mathrm{SO}_{4}(0.1 \%)$, $\mathrm{NaCl}(0.25 \%)$, and $\mathrm{CaCO}_{3}$ (0.1\%), $\mathrm{pH}$ 7.2. Fermentation was carried out at $180 \mathrm{rpm}$ for 4 days at $28^{\circ} \mathrm{C}$ on a rotary shaker.

\subsection{Extraction and Isolation}

The culture of $90 \mathrm{~L}$ of S. parvus 33 was filtered through cheesecloth to separate the medium and culture liquid at $25^{\circ} \mathrm{C}, \mathrm{pH}$ 7.0. The filtrate was absorbed onto HPD-100 macroporous resin, and then eluted with $\mathrm{MeOH}$. The $\mathrm{MeOH}$ fraction was evaporated in vacuum. The concentrate was subjected to column chromatography and eluted with petroleum ether and EtOAc, in sequence. The antimicrobial fraction was concentrated under vacuum, and further purified on a Waters 2695 HPLC apparatus equipped with a Sinochrom ODS-BP $(10.0 \mathrm{~mm} \times 300 \mathrm{~mm}, 10 \mu \mathrm{m})$ reverse phase column, using $50 \% \mathrm{MeOH} / \mathrm{H}_{2} \mathrm{O}$ as the mobile phase at flow rate of $3.0 \mathrm{~mL} / \mathrm{min}$, monitored by UV detector at 240 $\mathrm{nm}$ to afford two compounds ZM-1 and ZM-2. ZM-1 was obtained as a single crystal, and determined by single crystal diffraction. ZM-2 was obtained as colorless amorphous solid.

\subsection{Antimicrobial Activity}

\subsubsection{Inhibition of Bacteria}

Minimum inhibitory concentration (MIC) was (15) determined against bacteria using micro-dilution method (Method 96): $5 \mathrm{~mL}$ sterile MH broth was added to a test tube; using an inoculating needle, a small amount of bacterial broth was picked and added to the tube, placed in $37^{\circ} \mathrm{C}$ incubator for 12 hours. The absorbance of cell culture was measured using UV-Vis spectrophotometer at $600 \mathrm{~nm}$ against a culture medium without bacteria as blank control, according to each equivalent to a concentration of 0.1 $\mathrm{OD}_{600} 1 \times 10^{8} \mathrm{cfu} / \mathrm{mL}$, were diluted to a concentration of 1 $\times 10^{6} \mathrm{cfu} / \mathrm{mL}$.

To conduct tests with 96-well culture plates $(12 \times 8$, Ushaped hole at the end), $0.1 \mathrm{mg}$ of the test compound was first dissolved in $5 \mu \mathrm{L}$ dimethyl sulfoxide (DMSO), and then dissolved in $100 \mathrm{~mL}$ sterile water to be formulated at a concentration of $100 \mu \mathrm{g} / \mathrm{mL}$ as the mother liquor. The first test well was filled with $50 \mu \mathrm{L}$ maximum concentration of the drug solution, each of $50 \mu \mathrm{L}$ sterile water are added, the double dilution method using a gradient of 1 - 8 hole diluted to $500 \sim 3.9 \mu \mathrm{g} / \mathrm{mL}$ gradient series. The 9 th and 10 th holes were filled with $50 \mu$ L sterile water as negative control. Then, it was added at a concentration of 1 to 9 holes $1 \times$ $10^{6} \mathrm{cfu} / \mathrm{mL}$ of bacteria solution $50 \mu \mathrm{L}$, 10th hole by adding a blank incubation $50 \mu \mathrm{L}$ sterile water. The 11th hole was filled with $50 \mu \mathrm{L} 2.5 \%$ DMSO and $50 \mu \mathrm{L}$ solution at a concentration of $1 \times 10^{6} \mathrm{cfu} / \mathrm{mL}$ of the broth. The 12 th hole was filled with $100 \mu \mathrm{L}$ sterile water as blank. Then, the microporous oscillation mixing was performed in $37^{\circ} \mathrm{C}$ incubator while ampicillin was used as positive control. Each treatment was repeated three times.

12 hours after treatment, the results were observed: in the case of a black background light observation, there are 


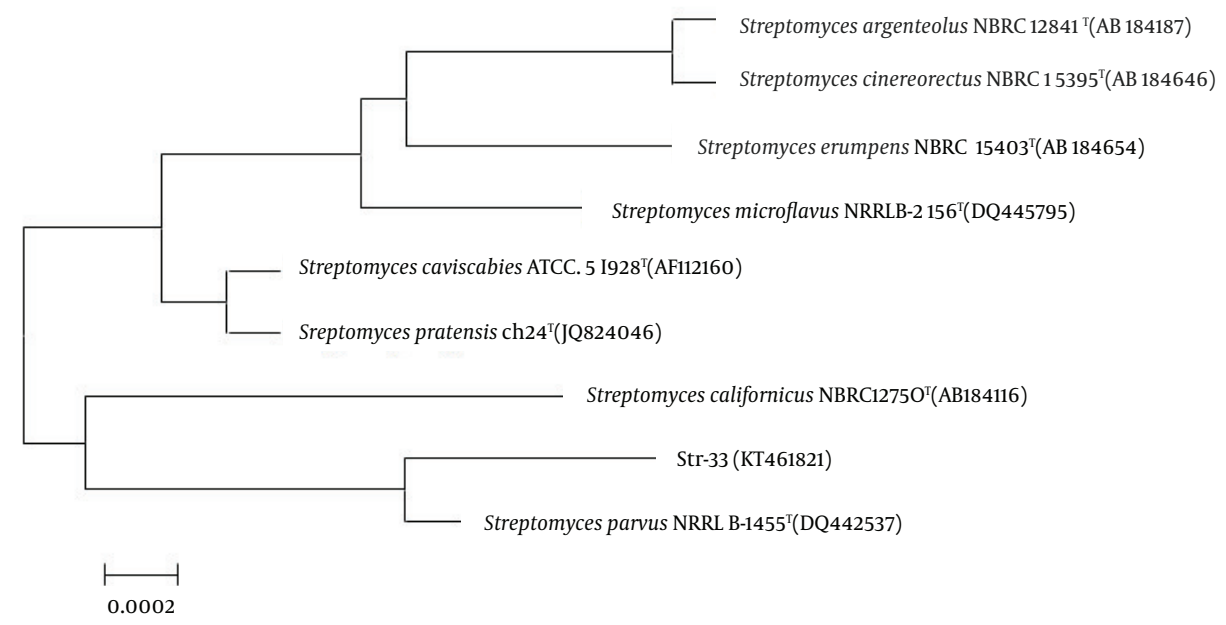

Figure 1. Phylogenetic Tree Based on 16S rDNA Sequences of Strain 33

holes in the bottom of the growth of bacteria precipitate or diffuse type turbidity, the lowest sample concentration of holes contained sterile growth inhibition is the lowest of the sample bacterial concentration (MIC).

\subsubsection{Inhibition of Plant Pathogenic Fungi}

Using suppression spore germination: pathogenic fungi spores will develop well paired with sterile water at a concentration of $1 \times 10^{5} \sim 1 \times 10^{7}$ spore suspension. 0.1 $\mathrm{mg}$ of the test compound was first dissolved in $10 \mu$ L DMSO, and then dissolved in $200 \mathrm{~mL}$ sterile water, formulated at a concentration of $50 \mu \mathrm{g} / \mathrm{mL}$ of the mother liquor (16). The agent activity was set at final concentrations of $25 \mu \mathrm{g} / \mathrm{mL}$, $12.5 \mu \mathrm{g} / \mathrm{mL}, 6.25 \mu \mathrm{g} / \mathrm{mL}$, as 3 liquid concentration gradients.

With a pipette to draw $25 \mu \mathrm{L}$ and $25 \mu$ L each concentration liquid droplets prepared spore suspension was added to the dry cleaner's concave slide, so that the liquid and mix equal amounts of spore suspension, then placed with shallow water dish, capped at $25^{\circ} \mathrm{C}$ constant moisture incubator. Each treatment was repeated three times against distilled water. When the control spore germination rate was more than $85 \%$, spores were checked in each treatment (per treatment were observed each repeated five horizons, the total number of spores survey less than 250) germination under an optical microscope. Table 2 shows a formula agent for inhibition rate of spore germination.

\section{Results}

\subsection{Chemistry}

The active ingredients were obtained by the techniques of macroporous resin adsorption, silica gel column chromatography, and preparative reverse phase high performance liquid chromatography. The compound ZM-1 was obtained in the form of a clear single crystal, and unambiguously confirmed by X-ray crystallography. ZM-2 was characterized by IR, ${ }^{1} \mathrm{H}$-NMR, ${ }^{13} \mathrm{C}$-NMR, DEPT $\left(90^{\circ}\right.$ and $\left.135^{\circ}\right)$, and MS analysis, as illustrated in Figure 2.

The compound ZM-2: colorless amorphous solid; HRESI-MS (positive) $\mathrm{m} / \mathrm{z}: 283.1059[\mathrm{M}+\mathrm{Na}]^{+}$(calcd for $\mathrm{C}_{14} \mathrm{H}_{16} \mathrm{~N}_{2} \mathrm{O}_{3} \mathrm{Na}$, 283.1059). ${ }^{1} \mathrm{HNMR}\left(400 \mathrm{MHz}, \mathrm{CD}_{3} \mathrm{OD}\right) \delta: 7.18$ - 7.32 (5H, m, H-12-H-16), 4.22 (2H, m, H-3 and $\mathrm{H}-8), 3.87(1 \mathrm{H}$, $\mathrm{dd}, \mathrm{J}=12.4,3.9 \mathrm{~Hz}, \mathrm{H}-9 \mathrm{a}), 3.27(1 \mathrm{H}, \mathrm{dd}, \mathrm{J}=12.6,4.9 \mathrm{~Hz}, \mathrm{H}-9 \mathrm{~b})$, $3.19(1 \mathrm{H}, \mathrm{dd}, \mathrm{J}=5.1,13.6 \mathrm{~Hz}, \mathrm{H}-10 \mathrm{a}), 3.00(1 \mathrm{H}, \mathrm{dd}, \mathrm{J}=4.8,13.6$ $\mathrm{Hz}, \mathrm{H}-10 \mathrm{~b}), 2.78(1 \mathrm{H}, \mathrm{t}, \mathrm{J}=8.5 \mathrm{~Hz}, \mathrm{H}-6), 2.23(1 \mathrm{H}, \mathrm{m}, \mathrm{H}-7 \mathrm{a})$, and $1.92(1 \mathrm{H}, \mathrm{m}, \mathrm{H}-7 \mathrm{~b}) ;{ }^{13} \mathrm{C}$ NMR $\left(\mathrm{CD}_{3} \mathrm{OD}\right) \delta: 170.98$ (C-5), 167.70 (C2),136.78 (C-11), 131.20 (C-12 and C-16), 129.70 (C-13 and C-15), 128.53 (C-14), 68.47 (C-8), 59.61 (C-3), 57.20 (C-6), 53.99 (C-9), $40.86(\mathrm{C}-10)$, and 38.0 (C-7).

\subsection{Biological Assay}

The antimicrobial activity of ZM- 1 and ZM-2 was measured according to a previously reported method. The biological activities of ZM-1 and ZM-2 towards a wide variety of bacterial and fungal plant pathogens were evaluated, giving the following results. The inhibitory effects of ZM1 against bacteria are listed in Table 1 . Antibacterial activities were measured by the micro-broth dilution method in 


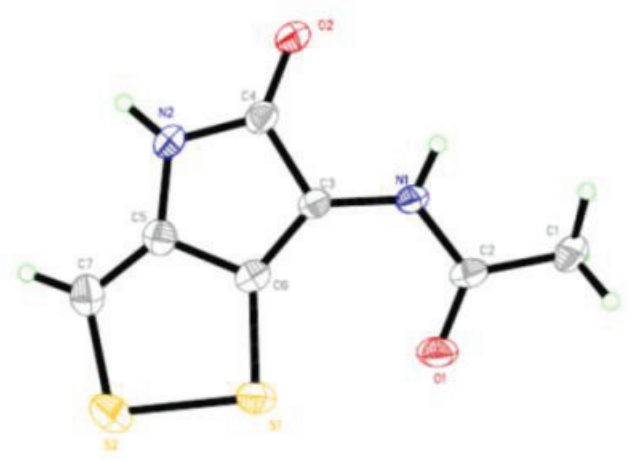

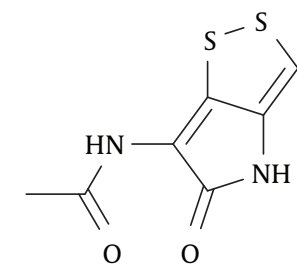

ZM-1<smiles>O=C1N[C@@H](Cc2ccccc2)C(=O)N2C[C@H](O)C[C@H]12</smiles>

ZM-2

Figure 2. X-Ray Crystal Structure and Chemical Structure of the Compound ZM-1 and ZM-2

96-well culture plates, with Ampicillin as a positive control, to evaluate the biological activities of the compound ZM-1 against the tested bacteria at different concentrations. For most of the tested strains, the minimum inhibitory concentration of the compound ZM-1 was $0.39 \mu \mathrm{g} / \mathrm{mL}$, which is less than that of the positive control ampicillin. Especially for the P. syringae pv. Actinidiae and the R. solanacearum, the value of MIC of the positive control was 160 times more than that of the compound ZM-1, which shows that the antibacterial ability of the compound ZM-1 is strong.

The inhibitory effects of ZM-1 against spore germination are listed in Table 2. Spore germination inhibition assay was utilized to investigate the biological activities of ZM-1. The compound ZM-1 exhibited a high degree of activity against the tested pathogenic fungi. The antimicrobial activity was enhanced with the increase of concentration of the compound ZM-1. However, ZM-2 was not effective against the tested bacterial and fungal plant pathogens.

The compounds ZM-1 and ZM-2 were isolated from the extract of the fermented broth of S. parvus 33 by bioassayguided fractionation. The compound ZM-1 was isolated in the form of a clear single crystal for the first time, and identified as holomycin via X-ray crystallography. Streptomyces parvus 33 is a newly discovered producer of holomycin. ZM1 showed a strong antibacterial activity against the tested bacteria, such as B. cereus, B. subtilis, E. coli, S. aureus, and P. syringaepv. actinidiae, and its value of MIC was greater than that of the positive control ampicillin. The compound ZM-1 exhibited a high degree of activity against F. oxysporumf. sp. vasinfectum, C. lunata, C. orbiculare, and C. gloesporioides. The antimicrobial activities were enhanced with the increased concentration of the compound ZM-1. How- ever, ZM-2 was not effective against the tested bacterial and fungal plant pathogens. In general, the compound ZM-1 is a valuable lead compound for the development of agricultural fungicides while acts against bacteria, as well.

\section{Acknowledgments}

This work was supported by the scientific and technology research program of Shaanxi province academy of sciences (2014K-26), the western light program of Chinese academy of sciences (2014), and the national natural science foundation of Shaanxi province (2016JQ3035).

\section{Footnotes}

Authors' Contribution: Wenjuan Zhang participated in the compound extraction and isolation and drafted the manuscript. Saijian Ma participated in antimicrobial activity experiments and the microorganism collection, culture, and storage. Chao An performed the identification of S. parvus 33. Wenjiao Xue participated in study design and revised the manuscript; all authors read and approved the final manuscript.

Financial Disclosure: The authors declare that no competing financial interests exist.

Funding/Support: This work was supported by the scientific and technology research program of Shaanxi Province academy of sciences (2014K-26), the western light program of Chinese academy of sciences (2014), and the national natural science foundation of Shaanxi province (2016JQ3035). 
Table 1. Minimum Inhibitory Concentration of the Compound ZM-1

\begin{tabular}{|c|c|c|}
\hline \multirow[t]{2}{*}{ Tested Bacteria } & \multicolumn{2}{|c|}{ Minimum Inhibitory Concentration MIC $(\mu \mathrm{g} / \mathbf{m L})$} \\
\hline & ZM-1 & Ampicillin \\
\hline Bacillus cereus & 0.78 & 3.13 \\
\hline Bacillus subtilis & 0.39 & 12.5 \\
\hline Staphylococcus aureus & 0.39 & 6.25 \\
\hline Escherichia coil & 0.39 & 25 \\
\hline Pseudomonas aeruginosa & $>50$ & 25 \\
\hline Pseuomonassyringaepv. Actinidiae & 0.39 & $>50$ \\
\hline Ralstoniasolanacearum & 0.39 & $>50$ \\
\hline
\end{tabular}

Table 2. Inhibitory Effects of the Compound ZM-1 Against Plant Pathogenic Fungi

\begin{tabular}{lrc}
\hline Tested Pathogenic Fungi & \multicolumn{2}{c}{ Inhibition Rate of Spore Germination $(\%)$} \\
\hline & $6.25 \mu \mathrm{g} / \mathrm{mL}$ & $12.5 \mu \mathrm{g} / \mathrm{mL}$ \\
\hline Fusariumoxysporum f sp. vasinfectum & $25.93 \pm 0.17$ & $69.14 \pm 0.34$ \\
\hline Curvularialunata & $24.44 \pm 1.39$ & $39.87 \pm 0.80$ \\
\hline Colletotrichumorbiculare & $23.36 \pm 0.73$ & $53.98 \pm 0.54$ \\
\hline Colletotrichumgloesporioides & $37.81 \pm 0.56$ & $96.19 \pm 0.45$ \\
\hline
\end{tabular}

\section{References}

1. Mansfield J, Genin S, Magori S, Citovsky V, Sriariyanum M, Ronald P, et al. Top 10 plant pathogenic bacteria in molecular plant pathology. Mol Plant Pathol. 2012;13(6):614-29. doi: 10.1111/j.1364-3703.2012.00804.x. [PubMed: 22672649].

2. Thomson CJ, Power E, Ruebsamen-Waigmann H, Labischinski H. Antibacterial research and development in the 21(st) Century-an industry perspective of the challenges. Curr Opin Microbiol. 2004;7(5):44550. doi: 10.1016/j.mib.2004.08.009. [PubMed: 15451498].

3. Watve MG, Tickoo R, Jog MM, Bhole BD. How many antibiotics are produced by the genus Streptomyces? Arch Microbiol. 2001;176(5):386-90. doi: 10.1007/s002030100345. [PubMed: 11702082].

4. Bode HB. Insect-associated microorganisms as a source for novel secondary metabolites with therapeutic potential. Springer Netherlands; 2011. pp. 77-93.

5. Spellberg B, Guidos R, Gilbert D, Bradley J, Boucher HW, Scheld WM, et al. The epidemic of antibiotic-resistant infections: a call to action for the medical community from the Infectious Diseases Society of America. Clin Infect Dis. 2008;46(2):155-64. doi: 10.1086/524891. [PubMed: 18171244].

6. Donadio S, Maffioli S, Monciardini P, Sosio M, Jabes D. Antibiotic discovery in the twenty-first century: current trends and future perspectives. J Antibiot (Tokyo). 2010;63(8):423-30. doi: 10.1038/ja.2010.62. [PubMed: 20551985].

7. Ji Z, Wang M, Wei S, Zhang J, Wu W. Isolation, structure elucidation and antibacterial activities of streptothricin acids. J Antibiot (Tokyo). 2009;62(5):233-7. doi: 10.1038/ja.2009.16. [PubMed: 19300469].

8. Ji Z, Wei S, Zhang J, Wu W, Wang M. Identification of streptothricin class antibiotics in the early-stage of antibiotics screening by electrospray ionization mass spectrometry. J Antibiot (Tokyo). 2008;61(11):660-7. doi:10.1038/ja.2008.93. [PubMed: 19168980].
9. Ji Z, Wang M, Zhang J, Wei S, Wu W. Two new members of streptothricin class antibiotics from Streptomyces qinlingensis sp. nov. $J$ Antibiot(Tokyo). 2007;60(12):739-44.doi:10.1038/ja.2007.96.[PubMed: 18276997].

10. Wang M, Yang XH, Wang JD, Wang XJ, Chen ZJ, Xiang WS. New beta-class milbemycin compound from Streptomyces avermitilis NEAU1069: fermentation, isolation and structure elucidation. J Antibiot (Tokyo). 2009;62(10):587-91. doi: 10.1038/ja.2009.78. [PubMed: 19680282].

11. Ji Z, Qiao G, Wei S, Fan L, Wu W. Isolation and characterization of two novel antibacterial cyclic hexapeptides from Streptomyces alboflavus 313. Chem Biodivers. 2012;9(8):1567-78. doi: 10.1002/cbdv.201100364. [PubMed: 22899617].

12. Ji Z, Wei S, Fan L, Wu W. Three novel cyclic hexapeptides from Streptomyces alboflavus 313 and their antibacterial activity. Eur J Med Chem. 2012;50:296-303. doi: 10.1016/j.ejmech.2012.02.008. [PubMed: 22365561].

13. Zhang W, Wei S, Zhang J, Wu W. Antibacterial activity composition of the fermentation broth of Streptomyces djakartensis NW35. Molecules. 2013;18(3):2763-8. doi: 10.3390/molecules18032763. [PubMed: 23455667].

14. Wu WJ, Zhang JW, Zhang WJ, Wei SP. Cheminform abstract: A new dihydrooxazole antibiotic from the fermentation broth of streptomyces djakartensis. Cheminform. 2014;45(52):1656-61.

15. Li LB, Dan WJ, Tan FF, Cui LH, Yuan ZP, Wu WJ, et al. Synthesis and Antibacterial Activities of Yanglingmycin Analogues. Chem Pharm Bull (Tokyo). 2014 [PubMed: 25355464].

16. Feng JT, Wang H, Ren SX, He J, Liu Y, Zhang X. Synthesis and antifungal activities of carabrol ester derivatives. J Agric Food Chem. 2012;60(15):3817-23. doi: 10.1021/jf205123d. [PubMed: 22443262]. 